\title{
Exclusion of calcitonin as a candidate gene for the basic defect in a family with autosomal dominant supravalvular aortic stenosis
}

\author{
C P BENNETT*, J BURN*, G E MOORE $\dagger$, J CHAMBERS $\dagger$, R WILLIAMSON $\dagger$, \\ AND J WILKINSON \\ From ${ }^{*}$ the Department of Human Genetics, University of Newcastle upon Tyne; the Department of \\ Biochemistry, St Mary’s Hospital Medical School, London; and ¥the Royal Liverpool Children’s Hospital, \\ Liverpool.
}

SUMmARY Supravalvular aortic stenosis (SVAS) may occur as an isolated autosomal dominant trait or as a feature of Williams syndrome. It has been suggested that a defect in calcitonin function may play a role in Williams syndrome. We have excluded calcitonin as a candidate gene for SVAS using a gene specific probe.

Supravalvular aortic stenosis (SVAS) may occur as an isolated autosomal dominant trait or as a feature of Williams syndrome. It has been suggested that SVAS and Williams syndrome represent differing manifestations of the same disorder. Overt hypercalcaemia is a recognised feature of Williams syndrome in the neonate, attracting the title idiopathic infantile hypercalcaemia (IIH), and animal studies suggest that fetal hypercalcaemia may be a direct cause of SVAS. Calcitonin is a peptide hormone secreted by the thyroid $\mathrm{C}$ cells in response to an increase in plasma calcium and one of its actions is to lower plasma calcium. The finding of marked hyperplasia of the C cells in an adult with SVAS, and demonstration of a blunted calcitonin response in five children with Williams syndrome but with no history of hypercalcaemia, has supported the suggestion that a defect in calcitonin function may play a role in Williams syndrome. ${ }^{1}$

In view of these observations it was decided to investigate calcitonin as a candidate gene in SVAS families where linkage analysis was possible. The calcitonin gene has been localised to chromosome $11 \mathrm{p} 15 .^{2}$ A TaqI polymorphism detects two common alleles $A 1$ and $A 2,6.5 \mathrm{~kb}$ and $8.0 \mathrm{~kb}$ in length respectively. ${ }^{3}$

\section{Methods}

Blood samples were obtained from living members of a family with SVAS which had been described previously in $1965 .^{4}$ Diagnosis was confirmed by left ventricular angiography and after surgery. Subjects I. 2 and II. 2 have not been investigated but are obligate gene carriers. Using Southern blotting techniques a ${ }^{32} \mathrm{P}$ labelled calcitonin gene probe ${ }^{5}$ was hybridised to a Southern blot of DNA from the family digested with TaqI.

\section{Results}

The results are as shown in the figure. In subjects III.1, III.2, and IV.1 SVAS is segregating with the A1 polymorphism, but affected subject III.4 does not have $\mathrm{A} 1$ and is a recombinant.

I

II

III

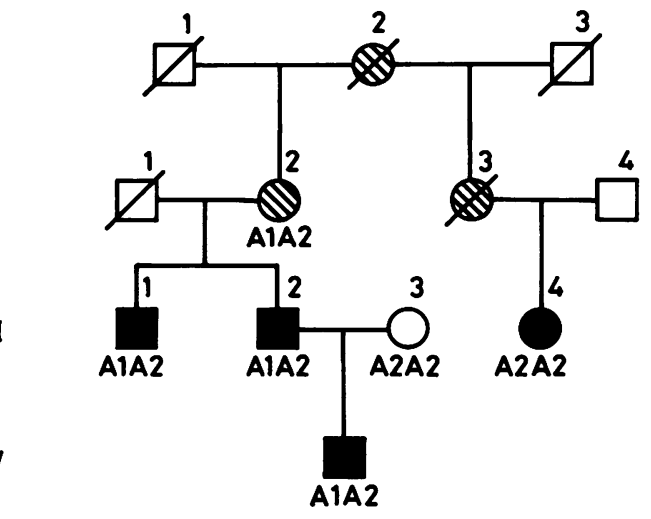

Affected

FIGURE Family pedigree. 


\section{Discussion}

These results exclude calcitonin as a candidate gene for SVAS in this family. This assumes an autosomal dominant mode of inheritance, that subjects I.2, II.2, or II.3 are not homozygotes, that persons marrying into the family are not asymptomatic gene carriers, and that no recombination within the calcitonin gene has occurred. It remains possible that SVAS is genotypically heterogeneous and the form of the disease reported here is distinct from that associated with Williams syndrome. If SVAS and Williams syndrome do belong to a single clinical spectrum we must deduce that a calcitonin gene defect is not responsible for the latter and the observed deficiency in calcitonin production is not the result of a primary gene defect.

On the broader front, this study illustrates the power of the candidate gene approach. In rare conditions or those where large pedigrees are unusual, gene localisation by linkage mapping is difficult or impossible. A viable approach to such disorders is to use a probe derived from a gene likely to be implicated in the cause. In this report one likely candidate has been effectively excluded using a single pedigree.

We would like to thank $\mathrm{Dr} \mathrm{R} \mathrm{K}$ Craig of the Middlesex Hospital for the use of the calcitonin probe phT-B3.

\section{References}

1 Burn J. Williams syndrome. J Med Genet 1986;23:389-95.

2 Höppener JWM. Steenbergh PH, Zandberg J, et al. Localization of the polymorphic human calcitonin gene on chromosome 11 Hum Genet 1984:66:309-12.

${ }^{3}$ Human Gene Mapping 8. Cytogenet Cell Genet 1986:40:188.

${ }^{4}$ Logan WFWE. Wyn Jones E. Walker E. Coulshed N. Epstein EJ. Familial supravalvular aortic stenosis. Br Heart J 1965:27: 547-59.

5 Allison J, Hall L. Macintyre I. Craig RK. The construction and the partial characterisation of plasmids containing complimentary DNA sequences to human calcitonin precursor polyprotein Biochem J 1981:199:725-31.

Correspondence and requests for reprints to $\operatorname{Dr} C \mathrm{P}$ Bennett, Department of Human Genetics, University of Newcastle upon Tyne, 19 Claremont Place, Newcastle upon Tyne NE2 4AA. 